\title{
Heterosis in sweet sorghum
}

\author{
Gabrielle Maria Romeiro Lombardi(1), Patricia Cardoso Andrade Navegantes ${ }^{(1)}$, Carlos Henrique Pereira ${ }^{(1)}$, \\ Jales Mendes Oliveira Fonseca(1), Rafael Augusto da Costa Parrella(2), Fernanda Maria Rodrigues Castro(1), \\ Mara Jane da Rocha( ${ }^{(1)}$, Daniela Oliveira Ornelas ${ }^{(1)}$, Adriano Teodoro Bruzi ${ }^{(1)}$ and José Airton Rodrigues Nunes ${ }^{(1)}$ \\ (1)Universidade Federal de Lavras, Campus Universitário, Caixa Postal 3.037, CEP 37200-000 Lavras, MG, Brazil. \\ E-mail: gabriellelombardi@hotmail.com, patty_andrade26@yahoo.com, chpereira88@hotmail.com, jalesmof@hotmail.com, \\ fefernandacastro@hotmail.com, marajane_r@hotmail.com, dani.ornelas@hotmail.com, adrianobruzi@dag.ufla.br, jarnunes@dbi.ufla.br \\ (2)Embrapa Milho e Sorgo, Rodovia MG-424, Km 45, CEP 35701-970 Sete Lagoas, MG, Brazil. E-mail: rafael.parrella@embrapa.br
}

\begin{abstract}
The objective of this work was to evaluate the potential per se of male-sterile and fertility-restorer lines of sweet sorghum (Sorghum bicolor), as well as to detail the heterosis manifested for some traits directly or indirectly related to ethanol production, accumulation rate, and predictability. Evaluations were performed for 20 genotypes, of which 4 are fertility-restorer lines (R), 3 are male-sterile lines (A), and 12 are experimental hybrids $(\mathrm{H})$ resulting from the partial diallel cross between lines $\mathrm{A}$ and $\mathrm{R}$, besides a commercial hybrid CV198 used as a check, in four harvest seasons. The experiments were carried out in the municipalities of Lavras and Sete Lagoas, in the state of Minas Gerais, Brazil. The measured traits were plant height, green mass production, juice extraction, total soluble solids content, and megagrams of Brix per hectare. The malesterile A1 and the fertility-restorer R1 and R3 lines show the best potential per se, considering all traits and their accumulation rate and predictability over harvest times. Heterosis is significant for all traits. The $\mathrm{H}_{11}, \mathrm{H}_{13}$, $\mathrm{H}_{14}, \mathrm{H}_{21}, \mathrm{H}_{22}$, and $\mathrm{H}_{33}$ hybrids are promising because of their better performance per se and higher heterosis.
\end{abstract}

Index terms: Sorghum bicolor, diallel, hybrid vigor, male-sterility, parental selection.

\section{Heterose em sorgo-sacarino}

Resumo - O objetivo deste trabalho foi avaliar o potencial per se de linhagens macho-estéreis e restauradoras de sorgo-sacarino (Sorghum bicolor), bem como detalhar a heterose manifestada quanto a algumas características relacionadas direta ou indiretamente à produção de etanol, à taxa de acúmulo e à previsibilidade. As avaliações foram realizadas com 20 genótipos, dos quais 4 linhagens restauradoras de fertilidade (R), 3 linhagens macho-estéreis (A) e 12 híbridos experimentais $(\mathrm{H})$ resultantes do cruzamento dialelo parcial entre as linhagens A e R, além de um híbrido comercial CV198 como testemunha, em quatro épocas de colheita. Os experimentos foram realizados nos municípios de Lavras e Sete Lagoas, no Estado de Minas Gerais. As características mensuradas foram altura de planta, produção de massa verde, extração de caldo, conteúdo de sólidos solúveis totais e megagramas de Brix por hectare. As linhagens macho-estéreis A1 e as restauradoras R1 e R2 apresentam melhor potencial per se, ao se considerar todos os caracteres e a sua taxa de acúmulo e a previsibilidade de comportamento, nas diferentes épocas de colheitas. A heterose é significativa para todos os caracteres. Os híbridos $\mathrm{H}_{11}, \mathrm{H}_{13}, \mathrm{H}_{14}, \mathrm{H}_{21}, \mathrm{H}_{22}$ e $\mathrm{H}_{33}$ são promissores por seu maior desempenho per se e maior heterose.

Termos para indexação: Sorghum bicolor, dialelo, vigor híbrido, macho-esterilidade, seleção parental.

\section{Introduction}

The increasing demand for energy, together with the finite reserves of petroleum and its derivatives, as well as concerns about environmental pollution have motivated worldwide research for renewable energy sources. In this regard, Brazil occupies a prominent position, as renewable sources account for $42 \%$ of the Brazilian energy consumption (EPE, 2015). An important productive chain is the ethanol production, which has sugarcane as its basic feedstock. However, the search for other bioenergy crops is relevant to better meet demand.

Sweet sorghum, Sorghum bicolor (L.) Moench, has several advantageous aspects with respect to the ethanol production as a complement to that of sugarcane (Elangovan et al., 2014; Santos et al., 2015). This crop shows favorable agroindustrial traits, such as soluble solids content ranging from 13 to $24^{\circ} \mathrm{Brix}$, 
total recoverable sugars around 80 to $127 \mathrm{~kg}$ sugar $\mathrm{Mg}^{-1}$ stalk, fully mechanizable and broad adaptability to cultivation (Kim \& Day, 2010; Regassa \& Wortmann, 2014).

In general, the heterotic effect in autogamous species is less effectively manifested than in allogamous ones; however, there are some examples of success, such as in rice (Pereira et al., 2008) and grain sorghum (Scapim et al., 1998). Studies on sweet sorghum have shown the existence of heterosis for traits directly or indirectly related to the ethanol production, including soluble solids content, green mass production, and juice yield (Pfeiffer et al., 2010; Bunphan et al., 2015; Reddy et al., 2007).

Thus, the establishment of heterosis-based breeding of sweet sorghum has been shown to be a viable alternative. In general, studies on sweet sorghum have shown the presence of genes with additive and nonadditive gene action, in the expression of traits related to ethanol production (Bunphan et al., 2015), emphasizing the justification of breeding to obtain hybrid cultivars.

In order to evaluate the potential of a hybrid, the phenotypic expression of several traits should be taken into account, especially those related to ethanol production, such as megagrams of Brix per hectare, total soluble solids, plant height, green mass production, and juice extraction (Lombardi et al., 2015). However, during the crop development, these traits vary (increase or decrease) in their phenotypic expression, which affects the recommendation of lines, hybrids, and the agroindustrial planning for the plants (Borèm et al., 2014).

In this context, the knowledge about the heterotic effect, exhibited during plant development, may help to better characterize the differential behavior of lines and hybrids. In addition to investigating the heterosis for the average performance, it is interesting to describe the heterotic effect for the accumulation rate of the traits that affect the ethanol yield over time, as well as for the predictability of the behavior of lines and hybrids.

The objective of this work was to evaluate the potential per se of male-sterile and fertility-restorer lines of sweet sorghum, as well as to detail the heterosis manifested for some traits directly or indirectly related to ethanol production, the accumulation rate, and the predictability, over four harvest times.

\section{Materials and Methods}

The experiments were carried out in the municipalities of Lavras and Sete Lagoas, in the state of Minas Gerais, Brazil, in the 2014/2015 growing season.

In Lavras $\left(21^{\circ} 14^{\prime} \mathrm{S}, 45^{\circ} 00^{\prime} \mathrm{W}\right.$, at $932 \mathrm{~m}$ altitude), the experiment was carried out in an experimental area of the Centro de Desenvolvimento Científico e Tecnológico em Agropecuária, Universidade Federal de Lavras. It has an annual average temperature of $19.4^{\circ} \mathrm{C}$, and annual rainfall of $1,529.7 \mathrm{~mm}$. The climate, according to the Köppen-Geiger's classification, is Cwa, temperate rainy (mesothermal) with dry winter and rainy summer, subtropical, with average temperature of the hottest month exceeding $22^{\circ} \mathrm{C}$ (February). The soil is classified as a Latossolo Vermelho-Amarelo (Santos et al., 2006), i.e., Oxisol, with a smooth undulating relief.

In Sete Lagoas (19 $27^{\prime} \mathrm{S}, 44^{\circ} 14^{\prime} 49^{\prime \prime} \mathrm{W}$, at $\left.767 \mathrm{~m}\right)$, the experiment was performed in an experimental area of Embrapa Milho e Sorgo. Sete Lagoas has an annual average temperature around $23^{\circ} \mathrm{C}$, and annual average rainfall of $1,403 \mathrm{~mm}$. The climate, according to the Köppen-Geiger's classification, is Cwa, temperate rainy with dry winter and rainy summer, subtropical, with average temperature of the hottest month exceeding $23.6^{\circ} \mathrm{C}$. The soil is classified as a Latossolo Vermelho (Santos et al., 2006), i.e., Oxisol, with smooth undulating relief.

The experimental material consisted of 20 genotypes belonging to the Sweet Sorghum Breeding Program of Embrapa Milho e Sorgo, from which 4 fertility-restorer lines (R), 3 male-sterile lines (A), and 12 experimental hybrids $(\mathrm{H})$ which resulted from the partial diallel cross between the lines R (group 1) and A (group 2), besides the commercial hybrid CV198 used as a check. The experimental hybrids were obtained by manual cross between male-sterile lines (female parents) and fertilityrestorer lines (male parents) under greenhouse conditions. Both the female and male parents had the panicle covered with a bag paper to avoid undesirable crosses.

The experiments were conducted in a triple rectangular lattice design with the treatments arranged in $20 x 4$ split plot scheme. The genotypes were randomized to whole plots following the experimental design, and the harvest times were randomized to split plots within the whole plots. The split plots consisted of a row with $5.0 \mathrm{~m}$ length spaced at $0.70 \mathrm{~m}$. 
The planting of the experiments took place on November $26^{\text {th }}, 2014$, in Lavras, and on December $7^{\text {th }}$, 2014, in Sete Lagoas. Fifteen days after emergence (DAE), thinning was performed to allow of the maintenance of 140,000 plants ha ${ }^{-1}$. At 20 DAE, topdressing was performed with $200 \mathrm{~kg}$ urea ha ${ }^{-1}$. Harvesting was done manually in four times, starting at 97 days after sowing or planting (DAP), with 14 days interval (97, 111, 125, and 139 DAP).

The measured traits were: plant height $(\mathrm{PH}, \mathrm{m})$, done through a measuring tape from the base of the plant to the apex of the panicle; green mass production (GMP, $\mathrm{Mg} \mathrm{ha}^{-1}$ ), weight of all plants of the split plot determined by a suspension scale; juice extraction (EXT, \%), percentage of juice extracted from six TSS stalks (whole plants without panicles and without leaves) by sugarcane milling (Lavras), or by hydraulic press (Sete Lagoas); total soluble solids content in percentage of juice (TSS, ${ }^{\circ}$ Brix), measured in homogenized juice sample by automatic digital refractometer; and megagrams of Brix per hectare (MBH), determined by multiplying GMP, EXT, and TSS values.

Initially, individual analyses of variance (per site) were performed for each trait evaluated considering the four harvests. Therefore, the joint analysis of the experiments for each trait was carried out. These analyses were run using the $\mathrm{R}$ software (R Core Team, 2016). The selective accuracy of each experiment was estimated as described in Resende \& Duarte (2007).

A simple linear regression was fitted for each whole plot over harvest times by the method of least squares, and the parameters $b_{1}$ and $r^{2}$ were estimated. Parameter $b_{1}$ represents the linear accumulation rate of traits over the harvests, and parameter $r^{2}$ reflects the predictability of the behavior of each genotype at the whole plot level. Some lines and hybrids showed negative values for parameter $b_{1}$ in certain traits. In these cases, a general constant was added so that all values became positive.

Diallel analyses were carried out according to the model of Miranda Filho \& Geraldi (1984), adapted from Gardner \& Eberhart (1966), using the expression $\mathrm{y}_{\mathrm{ar}}=\mu+\alpha \mathrm{d}+\left(\mathrm{v}_{\mathrm{a}}+\mathrm{v}_{\mathrm{r}}\right)+\theta+\mathrm{h}_{\mathrm{a}}+\mathrm{h}_{\mathrm{r}}+\mathrm{h}_{\mathrm{ar}}+\overline{\mathrm{e}}_{\mathrm{ar}}$, in which: $\mathrm{y}_{\mathrm{ar}}$ is the phenotypic mean of the trait, or estimate of $b_{1}$ or $r^{2}$ referring to the cross of the $a^{\text {th }}$ male-sterile line and the $r^{\text {th }}$ fertility-restorer line; $\alpha$ and $\theta$ are indicator variables, where $\alpha$ assumes the value 0 if the genotype is a hybrid combination, 1 if the genotype is a line A, or -1 if the genotype is a line $\mathrm{R}$, and $\theta$ assumes value 0 if it is a line $\mathrm{A}$ or $\mathrm{R}$, or 1 if it is a hybrid combination; $\mu$ is a constant; $\mathrm{v}_{\mathrm{a}}$ and $\mathrm{v}_{\mathrm{r}}$ are the effects of lines $\mathrm{A}$ and $\mathrm{R} ; \mathrm{h}$ is the average heterosis; and $h_{a}$ and $h_{r}$ are the heteroses assigned to lines $A$ and $R ; h_{a r}$ is the specific heterosis resulting from crossing the $\mathrm{a}^{\text {th }}$ male-sterile line, and the $\mathrm{r}^{\text {th }}$ from crossing the fertility-restorer line; and $\overline{\mathrm{e}}_{\mathrm{ar}}$ is the mean experimental error. Diallel analyses were performed with the Genes software (Cruz, 2013) and the significance of effects in the model was checked by the t-test, at $5 \%$ probability.

The contrast between the means of parental lines and the experimental hybrids was evaluated using the F-test, at 5\% probability. The mean of the commercial control (CV198) was compared to the means of male-sterile lines (A), fertility-restorer lines (R) and experimental hybrid $(\mathrm{H})$ strains by the Dunnett's test, at 5\% probability, using the SAS software (SAS Institute Inc., Cary, NC, USA).

\section{Results and Discussion}

The statistical analyses evidenced that the rectangular lattice experimental design showed low efficiency, so the analyses were accomplished considering a randomized complete block design. The experimental precision was verified through accuracy, which reflects the confidence in the estimation of real genotypic values from the phenotypic ones. According to Resende \& Duarte (2007), the experimental precision was considered very high with accuracy above $94 \%$ (Table 1).

The joint analysis detected significant differences between sites and harvest times for all traits, except for PH (Table 1). This fact may be related to differences of macroenvironmental aspects, such as rainfall and soil texture that influence the expression of the studied traits in the different sites. The differences among harvest times must be intrinsically related to the phenology of the crop, which refers to variable expressions of the traits.

The genotypes (lines and hybrids) were significantly different for all traits, and also showed differential responses for the MBH, GMP, and TSS, at different sites and harvest times (Table 1). Moreover, there was a significance for the effect of the triple interaction location $\mathrm{x}$ genotype $\mathrm{x}$ harvest time for $\mathrm{PH}$ and TSS, showing that, for these traits, the pattern of interaction genotype $\mathrm{x}$ harvest times was not consistent in both 
locations. This interaction requires more caution from the breeders to recommend genotypes; nonetheless, it allows the breeder to make specific recommendations, and to identify genotypes with broad adaptability. However, with the interaction evidence of genotype by location, we provided efforts to detail the genotypes effects for mean performance, as well as the linear accumulation rate and predictability for the traits over the harvest times, irrespectively of the site.

Considering the studied traits, the lines (A and R) and the hybrids showed significant differences (Tables 1 and 2), indicating the possibility of achieving highperformance cultivars by breeding sweet sorghum. This is evidenced when comparing the lines A and $\mathrm{R}$ and the hybrids with the control, with significant difference $(p<0.05)$ detected in some traits, such as for the hybrids, for juice extraction, which showed a statistically lower production than that of the control. Several studies have pointed out a wide variability of sweet sorghum genotypes. Elangovan et al. (2014) and Regassa \& Wortmann (2014) reported variations of plant height (2.77-3.11 m), juice extraction (29.0$75.8 \%$ ), total soluble solids content $(9.35-4.00 \%$ ), green mass production (36-140 $\mathrm{Mg} \mathrm{ha}^{-1}$ ), and $\mathrm{MBH}$ (0.6-8.1 Mg ha $\left.{ }^{-1}\right)$.

Additionally, lines A showed a lower phenotypic expression than the lines $\mathrm{R}$ and hybrids for all evaluated traits (Table 2). This result is associated with the seed production activities, in which the hybrid seed is collected from the lines A. Thus, the lines A should be shorter, but should associate high-sugar content. In this context, the lines A did not statistically distinguish between them, but the line A1 stood out, since it showed a higher performance per se for TSS, $\mathrm{MBH}$, and GMP, and a lower performance for $\mathrm{PH}$. These results are consistent with those of Souza et al. (2016) and Reddy et al. (2007), however, the lines $\mathrm{A}$ in the present work have already shown a greater vegetative development, resulting from the selection that has been made.

Lines $\mathrm{R}$ showed a high performance per se, considering all evaluated traits, except for the lines R2 and R4 for EXT and TSS, respectively (Table 2). These two traits are correlated with the production of ethanol, and are also components evaluated for the crop ideotype. Thus, although they have exhibited a better performance for the other traits, the recommendation and the use for hybrid combinations is affected. The lines R1 and R3 showed the highest potential per se, considering the mean performance over the harvest times.

As to hybrid combinations regarding the mean performance over the harvest times, it was observed that, in general, heterosis occurred for all evaluated

Table 1. Analysis of variance for the traits plant height (PH), green mass production (GMP), juice extraction (EXT), total soluble solids (TSS), and megagrams of Brix per hectare (MBH) for the evaluation of sweet sorghum genotypes in the municipalities of Lavras and Sete Lagoas, Minas Gerais state, Brazil, in the 2014/2015 growing season.

\begin{tabular}{|c|c|c|c|c|c|c|}
\hline \multirow[t]{2}{*}{ Source of variation } & \multirow[t]{2}{*}{ Degree of freedom } & \multicolumn{5}{|c|}{ Mean square } \\
\hline & & $\mathrm{PH}(\mathrm{m})$ & $\operatorname{GMP}\left(\mathrm{Mg} \mathrm{ha}^{-1}\right)$ & EXT $(\%)$ & TSS (\% juice) & $\mathrm{MBH}$ \\
\hline Location (L) & 1 & 0.005 & $8951 * *$ & $118649 * *$ & $352.6^{* *}$ & $146.7^{* *}$ \\
\hline Genotype (G) & 19 & $5.300^{* *}$ & $2433 * *$ & $242.80 * *$ & $29.76^{* *}$ & $17.27^{* *}$ \\
\hline $\mathrm{G} \times \mathrm{L}$ & 19 & $0.310^{* *}$ & $392.8^{* *}$ & $67.63^{*}$ & $9.71 * *$ & $3.19^{* *}$ \\
\hline Time (E) & 3 & 0.039 & $2954.4 * *$ & $273.19 * *$ & $118.60 * *$ & $4.01 * *$ \\
\hline $\mathrm{G} \times \mathrm{E}$ & 57 & 0.049 & $140.5^{*}$ & 17.64 & $5.57^{* *}$ & $1.36^{* *}$ \\
\hline $\mathrm{L} \times \mathrm{E}$ & 3 & $0.540^{* *}$ & $2656.2 * *$ & $291.31 * *$ & $68.73^{* *}$ & $45.61^{* *}$ \\
\hline $\mathrm{L} \times \mathrm{G} \times \mathrm{E}$ & 57 & $0.088 * *$ & 105.2 & 22.12 & $1.70 * *$ & 0.95 \\
\hline Overall mean & & 2.76 & 56.22 & 52.18 & 12.68 & 3.64 \\
\hline Male-sterile lines (A) & & $1.73^{+}$ & $35.29^{+}$ & $46.76^{+}$ & $11.09^{+}$ & $1.77^{+}$ \\
\hline Fertility-restorer lines $(\mathrm{R})$ & & $3.09^{+}$ & 64.73 & $54.62^{+}$ & 12.43 & 4.11 \\
\hline Experimental hybrids & & $2.86^{+}$ & $57.85^{+}$ & 52.86 & $13.21^{+}$ & 3.94 \\
\hline Commercial hybrid CV198 & & 3.29 & 65.44 & 50.47 & 12.19 & 3.85 \\
\hline CV (a) $(\%)$ & & 9.10 & 19.70 & 10.99 & 8.96 & 28.80 \\
\hline CV (b) $(\%)$ & & 8.43 & 17.66 & 9.36 & 8.08 & 23.46 \\
\hline AS $(\%)$ & & 97.86 & 99.49 & 97.95 & 94.96 & 98.22 \\
\hline
\end{tabular}

***Significant by the F-test, at 5 and $1 \%$ probability, respectively. ${ }^{+}$Significant by the Dunnett's test, at $5 \%$ probability, of the commercial hybrid. CV (a), coefficients of variation at plot level; CV (b), coefficients of variation at split plot level. AS, selective accuracy at split plot level. 
traits (Table 3). By the performance of lines A and $\mathrm{R}$ was possible to observe that the hybrid performance and the hybrids, along the development of the crop, it tends to approach the lines $\mathrm{R}$, thus highlighting the

Table 2. Summary of the mean performance $(\bar{y})$, accumulation rate $\left(b_{1}\right)$, and predictability $\left(r^{2}\right)$ of sweet sorghum genotypes for the traits plant height (PH), green mass production (GMP), juice extraction (EXT), total soluble solids (TSS), and megagrams of Brix per hectare (MBH) of sweet sorghum genotypes, over the harvest times in the municipalities of Lavras and Sete Lagoas, in the state of Minas Gerais, Brazil, in the 2014/2015 growing season.

\begin{tabular}{|c|c|c|c|c|c|c|c|c|c|c|c|c|c|}
\hline \multirow[t]{2}{*}{ Genotype } & \multirow{2}{*}{$\begin{array}{c}\mathrm{PH}(\mathrm{m}) \\
\bar{y}\end{array}$} & \multicolumn{3}{|c|}{$\operatorname{GMP}\left(\mathrm{Mg} \mathrm{ha}^{-1}\right)$} & \multicolumn{3}{|c|}{$\operatorname{EXT}(\%)$} & \multicolumn{3}{|c|}{ TSS ( $\%$ juice) } & \multicolumn{3}{|c|}{$\mathrm{MBH}$} \\
\hline & & $\bar{y}$ & $\mathrm{~b}_{1}$ & $\mathrm{r}^{2}$ & $\overline{\mathrm{y}}$ & $\mathrm{b}_{1}$ & $\mathrm{r}^{2}$ & $\overline{\mathrm{y}}$ & $\mathrm{b}_{1}$ & $\mathrm{r}^{2}$ & $\overline{\mathrm{y}}$ & $\mathrm{b}_{1}$ & $r^{2}$ \\
\hline A1 & $1.7 \mathrm{c}^{+}$ & $38 \mathrm{c}$ & -0.4 & 0.56 & $46 \mathrm{~b}$ & -0.02 & 0.59 & $11 \mathrm{c}$ & -0.04 & 0.36 & $2.0 \mathrm{~b}$ & -0.03 & 0.52 \\
\hline A2 & $1.8 \mathrm{c}$ & $35 b$ & -0.4 & 0.53 & $47 \mathrm{~b}$ & 0.02 & 0.12 & $11 \mathrm{c}$ & -0.04 & 0.53 & $1.8 \mathrm{~b}$ & -0.04 & 0.51 \\
\hline A3 & $1.7 \mathrm{c}$ & $33 b$ & -0.2 & 0.42 & $46 \mathrm{~b}$ & -0.04 & 0.10 & $11 \mathrm{c}$ & -0.06 & 0.55 & $1.6 \mathrm{~b}$ & -0.02 & 0.73 \\
\hline R1 & $3.0 \mathrm{a}$ & $65 \mathrm{a}$ & 0.1 & 0.35 & $56 \mathrm{a}$ & -0.09 & 0.42 & $12 \mathrm{a}$ & 0.12 & 0.79 & $4.4 \mathrm{a}$ & 0.04 & 0.43 \\
\hline R2 & $3.3 \mathrm{a}$ & $61 \mathrm{a}$ & -0.5 & 0.61 & $49 \mathrm{~b}$ & -0.20 & 0.43 & $13 \mathrm{a}$ & 0.11 & 0.69 & $3.8 \mathrm{a}$ & -0.02 & 0.52 \\
\hline R3 & $3.0 \mathrm{a}$ & $59 \mathrm{a}$ & 0.0 & 0.37 & $55 \mathrm{a}$ & -0.03 & 0.52 & $13 a$ & 0.09 & 0.63 & $4.0 \mathrm{a}$ & 0.02 & 0.62 \\
\hline R4 & $3.1^{\mathrm{a}}$ & $74 \mathrm{a}$ & -0.5 & 0.49 & $58 \mathrm{a}$ & 0.00 & 0.38 & $11 \mathrm{c}$ & 0.11 & 0.69 & $4.2 \mathrm{a}$ & 0.01 & 0.55 \\
\hline $\mathrm{H}_{11}$ & $2.8 \mathrm{~b}$ & $59 \mathrm{a}$ & 0.2 & 0.41 & $54 \mathrm{a}$ & -0.07 & 0.42 & $14 \mathrm{a}$ & 0.08 & 0.91 & $4.3 \mathrm{a}$ & 0.03 & 0.49 \\
\hline $\mathrm{H}_{12}$ & $2.9^{\mathrm{a}}$ & $58 \mathrm{a}$ & -0.3 & 0.37 & $51 \mathrm{~b}$ & -0.21 & 0.56 & $14 \mathrm{a}$ & 0.06 & 0.57 & $4.1 \mathrm{a}$ & -0.03 & 0.35 \\
\hline $\mathrm{H}_{13}$ & $2.8 \mathrm{~b}$ & $61 \mathrm{a}$ & -0.2 & 0.23 & $52 \mathrm{~b}$ & -0.07 & 0.44 & $14 \mathrm{a}$ & 0.07 & 0.69 & $4.4 \mathrm{a}$ & -0.00 & 0.32 \\
\hline $\mathrm{H}_{14}$ & $2.8 \mathrm{~b}$ & $56 \mathrm{a}$ & -0.4 & 0.47 & $54 \mathrm{a}$ & 0.04 & 0.58 & $12 b$ & 0.03 & 0.57 & $3.6 \mathrm{a}$ & -0.02 & 0.58 \\
\hline $\mathrm{H}_{21}$ & $2.7 \mathrm{~b}$ & $57 \mathrm{a}$ & -0.3 & 0.44 & $52 \mathrm{a}$ & -0.12 & 0.58 & $13 a$ & 0.08 & 0.82 & $3.9 \mathrm{a}$ & -0.01 & 0.53 \\
\hline $\mathrm{H}_{22}$ & $2.9^{\mathrm{a}}$ & $59 \mathrm{a}$ & -0.1 & 0.20 & $51 \mathrm{~b}$ & -0.08 & 0.43 & $14 \mathrm{a}$ & 0.08 & 0.66 & $4.3 \mathrm{a}$ & 0.01 & 0.26 \\
\hline $\mathrm{H}_{23}$ & $2.9 \mathrm{~b}$ & $55 \mathrm{a}$ & -0.3 & 0.27 & $55 \mathrm{a}$ & -0.05 & 0.20 & $13 a$ & 0.05 & 0.65 & $3.9 \mathrm{a}$ & -0.02 & 0.27 \\
\hline $\mathrm{H}_{24}$ & $2.7 \mathrm{~b}$ & $59 \mathrm{a}$ & -0.5 & 0.58 & $54 \mathrm{a}$ & 0.04 & 0.22 & $12 b$ & 0.03 & 0.73 & $3.7 \mathrm{a}$ & -0.03 & 0.37 \\
\hline $\mathrm{H}_{31}$ & $2.8^{\mathrm{b}}$ & $58 \mathrm{a}$ & -0.2 & 0.58 & $51 \mathrm{~b}$ & -0.06 & 0.56 & $14 \mathrm{a}$ & 0.08 & 0.74 & $3.9 \mathrm{a}$ & -0.00 & 0.60 \\
\hline $\mathrm{H}_{32}$ & $3.0 \mathrm{a}$ & $52 \mathrm{a}$ & -0.3 & 0.44 & $49 \mathrm{~b}$ & -0.09 & 0.54 & $13 a$ & 0.04 & 0.68 & $3.4 \mathrm{a}$ & -0.02 & 0.24 \\
\hline $\mathrm{H}_{33}$ & $2.9^{\mathrm{a}}$ & $57 \mathrm{a}$ & -0.3 & 0.46 & $55 \mathrm{a}$ & -0.04 & 0.29 & $13 a$ & 0.06 & 0.55 & $4.0 \mathrm{a}$ & -0.01 & 0.38 \\
\hline $\mathrm{H}_{34}$ & $2.8 \mathrm{~b}$ & $62 \mathrm{a}$ & -0.3 & 0.19 & $54 \mathrm{a}$ & -0.03 & 0.46 & $12 \mathrm{~b}$ & 0.04 & 0.50 & $3.9 \mathrm{a}$ & -0.01 & 0.19 \\
\hline
\end{tabular}

${ }^{+}$Mean values followed by different letters, in the columns, belong to different clusters, by Scott-Knott's test, at 5\% probability. A, male-sterile lines; R, fertility-restorer lines; $\mathrm{H}$, experimental hybrids.

Table 3. Summary of the partial diallel analysis of the mean performance $(\bar{y})$ over harvest times, for the traits plant height (PH), green mass production (GMP), juice extraction (EXT), total soluble solids (TSS), and megagrams of Brix per hectare (MBH) of sweet sorghum genotypes, in the municipalities of Lavras and Sete Lagoas, in the state of Minas Gerais, in the 2014/2015 growing season.

\begin{tabular}{|c|c|c|c|c|c|c|}
\hline \multirow[t]{2}{*}{ Source of variation } & \multirow{2}{*}{$\begin{array}{l}\text { Degree of } \\
\text { freedom }\end{array}$} & \multicolumn{5}{|c|}{ Mean square } \\
\hline & & $\mathrm{PH}(\mathrm{m})$ & GMP $\left(\mathrm{Mg} \mathrm{ha}^{-1}\right)$ & EXT $(\%)$ & TSS ( $\%$ juice) & $\mathrm{MBH}$ \\
\hline Genotype & (18) & $5.16^{*}$ & $2447.76^{*}$ & $252.08^{*}$ & $31.07^{*}$ & $18.14^{*}$ \\
\hline Between lines & 1 & $68.12 *$ & $32722.17 *$ & $2321.49 *$ & $48.59^{*}$ & $194.26^{*}$ \\
\hline Lines A & 2 & 0.05 & 126.32 & 15.37 & $6.28 *$ & $2.74^{*}$ \\
\hline Lines $\mathrm{R}$ & 3 & $0.89 *$ & $815.64 *$ & $461.46^{*}$ & $86.13^{*}$ & 1.51 \\
\hline Heterosis (H.) & (12) & $1.89 *$ & $719.82 *$ & $66.74 *$ & $19.98^{*}$ & $10.16^{*}$ \\
\hline Average $\mathrm{H}$. & 1 & $21.56^{*}$ & $6429.60 *$ & $491.64 *$ & $219.19^{*}$ & $104.03 *$ \\
\hline H. Line (A) & 2 & $0.25^{*}$ & 29.83 & 3.67 & 1.11 & 0.12 \\
\hline H. Line (R) & 3 & $0.16^{*}$ & 250.69 & 19.41 & 1.21 & 1.71 \\
\hline Specific $\mathrm{H}$. & 6 & 0.01 & $232.76^{*}$ & 40.62 & $2.45^{*}$ & $2.09 *$ \\
\hline Error & 228 & 0.05 & 99.70 & 24.62 & 1.04 & 0.74 \\
\hline Overall mean & & 2.76 & 56.22 & 52.18 & 12.68 & 3.64 \\
\hline Male-sterile lines (A) & & 1.73 & 35.29 & 46.76 & 11.09 & 1.77 \\
\hline Fertility-restorer lines (R) & & 3.09 & 64.73 & 54.62 & 12.43 & 4.11 \\
\hline Experimental hybrids & & $2.86^{+}$ & $57.85^{+}$ & $52.86^{+}$ & $13.21^{+}$ & $3.94^{+}$ \\
\hline
\end{tabular}

*Significant by the F-test, at $5 \%$ probability. ${ }^{+}$Significant by the contrast between the mean of lines A and R, and the mean of hybrids, by the F-test, at $5 \%$ probability. Lines A, male-sterile lines; lines R, fertility-restorer lines. 
heterotic effect found in the diallel analysis. This fact indicates that in the genetic control of these traits, nonadditive genes are involved, with the possibility of obtaining promising hybrid combinations. When estimating the combining ability, Bunphan et al. (2015) pointed out the nonadditive gene action for plant height, total biomass production, juice extraction, total soluble solids, sugar yield, and ethanol production.

In a detailed analysis of the manifested heterosis, the traits showed significance for the average heterosis (Table 3), indicating that there is a divergence in the allelic frequencies in the lines, which results in a favorable situation for breeding (Cruz \& Vencovsky, 1989). In this case, estimates of varietal heterosis are of fundamental importance with respect to the genetic significance, both in their signal and in their magnitude. The higher and more positive the magnitude of varietal heterosis $\left(h_{a}\right.$ or $\left.h_{r}\right)$, the better the hybrid contribution obtained (Cruz et al., 2012).

A varietal heterotic effect was observed for $\mathrm{PH}$ in both A and R lines. Among the A lines, the line A3 had a positive heterotic effect that resulted in higher hybrid combinations. Among the lines R, this same type of heterotic effect was observed for the line R3 (Tables 3 and 4). Similar results were reported by Kulkarni \& Shinde (1985). For GMP, EXT, TSS, and MBH, both $A$ and $\mathrm{R}$ lines did not differ for their varietal heterotic effect. These results differ from those of Pothisoong \& Jaisil (2011), who reported significant varietal heterotic effect with respect to the lines R, for EXT, TSS, and $\mathrm{MBH}$. Nevertheless, each study was conducted with a set of specific genotypes, therefore, this divergence in the results is justifiable.

For the traits GMP, TSS, and $\mathrm{MBH}$, there was a significant specific heterotic effect (Table 3). The

Table 4. Estimates of the effects of average heterosis $(\hbar)$, varietal heterosis $\left(h_{a}\right.$ and $\left.h_{r}\right)$, and the specific heterosis $\left(h_{a r}\right)$ of the mean performance $(\bar{y})$, accumulation rate $\left(b_{1}\right)$, and predictability $\left(\mathrm{r}^{2}\right)$ over harvest times, for the traits plant height $(\mathrm{PH}, \mathrm{m})$, green mass production (GMP, Mg ha-1), juice extraction (EXT, \%), total soluble solids (TSS, \% juice), and megagrams of Brix per hectare (MBH) of sweet sorghum genotypes, in the municipalities of Lavras and Sete Lagoas, in the state of Minas Gerais, Brazil, in the 2014/2015 growing season.

\begin{tabular}{|c|c|c|c|c|c|c|c|c|c|c|c|c|c|}
\hline \multirow{3}{*}{$\begin{array}{l}\text { Geno- } \\
\text { types }\end{array}$} & \multicolumn{10}{|c|}{ Trait } & \multirow{2}{*}{\multicolumn{3}{|c|}{$\mathrm{MBH}$}} \\
\hline & \multirow{2}{*}{$\begin{array}{c}\mathrm{PH} \\
\overline{\mathrm{y}} \\
\end{array}$} & \multicolumn{3}{|c|}{ GMP } & \multicolumn{3}{|c|}{ EXT } & \multicolumn{3}{|c|}{ TSS } & & & \\
\hline & & $\bar{y}$ & $\mathrm{~b}_{1}$ & $\mathrm{r}^{2}$ & $\overline{\mathrm{y}}$ & $\mathrm{b}_{1}$ & $\mathrm{r}^{2}$ & $\bar{y}$ & $\mathrm{~b}_{1}$ & $\mathrm{r}^{2}$ & $\bar{y}$ & $\mathrm{~b}_{1}$ & $r^{2}$ \\
\hline & $0.45^{*}$ & $7.8 *$ & $0.02 *$ & $-0.09 *$ & $2.17^{*}$ & $-0.01 *$ & $0.10^{*}$ & $1.45^{*}$ & $0.03 *$ & $0.08^{*}$ & $0.99 *$ & $0.00 *$ & $-0.18 *$ \\
\hline & \multicolumn{13}{|c|}{ Varietal H. $\left(h_{a}\right.$ or $\left.h_{r}\right)$} \\
\hline A1 & 0.02 & -0.7 & $0.11 *$ & -0.05 & 0.07 & -0.01 & $-0.12^{*}$ & 0.17 & 0.00 & $0.07 *$ & 0.05 & 0.01 & $0.08 *$ \\
\hline A2 & $-0.1 *$ & -0.1 & -0.01 & -0.03 & 0.24 & -0.01 & -0.02 & -0.05 & 0.00 & 0.02 & -0.01 & 0.00 & 0.01 \\
\hline A3 & $0.06^{*}$ & 0.8 & -0.1 & 0.07 & -0.3 & 0.02 & $0.14 *$ & -0.12 & 0.00 & $-0.08 *$ & -0.04 & -0.01 & $-0.97 *$ \\
\hline $\mathrm{R} 1$ & -0.05 & 0.1 & -0.03 & $0.14^{*}$ & -0.79 & -0.02 & $0.09 *$ & 0.23 & $0.02 *$ & $0.12 *$ & -0.05 & 0.00 & $0.11 *$ \\
\hline $\mathrm{R} 2$ & 0.04 & 0.5 & $0.16^{*}$ & -0.13 & 0.43 & -0.001 & 0.07 & 0.01 & 0.00 & -0.03 & 0.13 & $0.01 *$ & $-0.09 *$ \\
\hline R3 & $0.07 *$ & 2.7 & -0.12 & -0.02 & 0.7 & -0.02 & $-0.17^{*}$ & -0.08 & 0.01 & -0.01 & 0.19 & -0.01 & $-0.10^{*}$ \\
\hline \multirow[t]{2}{*}{$\mathrm{R} 4$} & -0.06 & -3.3 & -0.01 & 0.01 & -0.35 & 0.04 & 0.01 & -0.17 & $-0.02 *$ & $-0.07 *$ & -0.27 & $-0.01 *$ & -0.01 \\
\hline & \multicolumn{13}{|c|}{ Specific heterosis $\left(\mathrm{h}_{\mathrm{ar}}\right)$} \\
\hline $\mathrm{H}_{11}$ & -0.02 & 0.6 & -0.06 & 0.07 & -0.91 & 0.02 & 0.00 & 0.25 & 0.01 & -0.03 & 0.05 & -0.01 & $0.09 *$ \\
\hline $\mathrm{H}_{12}$ & 0.01 & $-3.8 *$ & -0.02 & 0.07 & -0.70 & 0.03 & 0.00 & -0.29 & $-0.02 *$ & $0.11 *$ & -0.4 & -0.01 & -0.01 \\
\hline $\mathrm{H}_{13}$ & 0.00 & -0.1 & -0.05 & $0.11^{*}$ & 1.25 & 0.01 & 0.00 & 0.07 & 0.01 & -0.03 & 0.08 & 0.00 & $0.09 *$ \\
\hline $\mathrm{H}_{14}$ & 0.02 & $3.3^{*}$ & 0.12 & -0.25 & 0.36 & -0.05 & 0.00 & -0.02 & 0.01 & -0.05 & $0.27 *$ & $0.01 *$ & $-0.16^{*}$ \\
\hline $\mathrm{H}_{21}$ & -0.01 & -0.4 & -0.16 & -0.02 & -0.09 & -0.04 & $0.14^{*}$ & -0.2 & 0.00 & -0.05 & -0.14 & $-0.01 *$ & 0.02 \\
\hline $\mathrm{H}_{22}$ & 0.01 & $2.9 *$ & $0.17 *$ & -0.12 & 0.22 & 0.04 & 0.01 & $0.38^{*}$ & $0.02 *$ & -0.02 & $0.37 *$ & $0.02 *$ & 0.00 \\
\hline $\mathrm{H}_{23}$ & 0.02 & -2.5 & 0.05 & -0.04 & 0.78 & -0.01 & -0.03 & -0.36 & $-0.01 *$ & -0.02 & -0.19 & 0.00 & -0.03 \\
\hline $\mathrm{H}_{24}$ & -0.01 & -0.1 & -0.07 & $0.18^{*}$ & -0.91 & 0.01 & $-0.12^{*}$ & 0.18 & -0.01 & $0.09 *$ & -0.03 & -0.01 & 0.02 \\
\hline $\mathrm{H}_{31}$ & 0.04 & -0.1 & $0.22 *$ & -0.05 & 1.00 & 0.03 & $-0.16 *$ & -0.04 & 0.00 & $0.08 *$ & 0.09 & $0.02 *$ & $-0.11 *$ \\
\hline $\mathrm{H}_{32}$ & -0.01 & 0.9 & -0.15 & 0.05 & 0.48 & -0.07 & -0.01 & -0.09 & 0.00 & $-0.08^{*}$ & 0.04 & $-0.02 *$ & 0.02 \\
\hline $\mathrm{H}_{33}$ & -0.01 & 2.5 & -0.01 & -0.07 & -2.03 & 0.01 & $0.07 *$ & 0.29 & 0.01 & 0.05 & 0.12 & 0.00 & -0.06 \\
\hline $\mathrm{H}_{34}$ & -0.01 & $-3.2 *$ & -0.06 & 0.07 & 0.55 & 0.04 & $0.10^{*}$ & -0.15 & 0.00 & -0.04 & -0.25 & 0.00 & $0.15^{*}$ \\
\hline
\end{tabular}

*Significant by the t-test, at 5\% probability . A, male-sterile lines; R, fertility-restorer lines; H, experimental hybrids. 
hybrid combinations $\mathrm{H}_{14}$ and $\mathrm{H}_{22}$ showed significant specific heterotic effect of positive magnitude (Table 4). However, when observing the performance per se, the hybrid $\mathrm{H}_{22}$ stood out in relation to the $\mathrm{H}_{14}$, with superior performance for all traits, except for EXT (Table 2).

When evaluating the accumulation rate of GMP, EXT, TSS, MBH, and the predictability of the behavior of the genotypes for these traits over harvest times, the behavior of the lines A and R and the hybrids, during the development of the crop, was observed as not highly predictable. This indicates that the response of the genotypes throughout the harvest times was not linear (Tables 5 and 6). Relatively higher estimates of predictability were registered for GMP and TSS. In general, for GMP, a decline was observed, while for TSS an increase of the phenotypic expression was observed along the crop development, confirming the result reported by Souza et al. (2016).

As to the accumulation rate of traits, there was heterosis for GMP, TSS, and MBH (Table 5). The traits showed significance regarding the average heterosis, highlighting the importance of studying

Table 5. Summary of the partial diallel analysis of the accumulation rate $\left(b_{1}\right)$ over the harvest times, for the traits green mass production (GMP, $\mathrm{Mg} \mathrm{ha}^{-1}$ ), juice extraction (EXT, \%), total soluble solids (TSS, \% juice), and megagrams of Brix per hectare (MBH) of sweet sorghum genotypes, in the municipalities of Lavras and Sete Lagoas, in the state of Minas Gerais, Brazil, in the 2014/2015 growing season.

\begin{tabular}{lccccc}
\hline \multirow{2}{*}{$\begin{array}{l}\text { Sources of } \\
\text { variation }\end{array}$} & \multirow{2}{*}{$\begin{array}{c}\text { Degree of } \\
\text { freedom }\end{array}$} & \multicolumn{5}{c}{ Mean square } \\
\cline { 3 - 6 } Genotype & $(18)$ & $0.819^{*}$ & $0.106^{*}$ & $0.0629^{*}$ & $0.010^{*}$ \\
Between lines & 1 & $0.518^{*}$ & $0.164^{*}$ & $0.946^{*}$ & $0.076^{*}$ \\
Line A & 2 & $0.429^{*}$ & 0.028 & 0.004 & 0.001 \\
Line R & 3 & $2.249^{*}$ & $0.407^{*}$ & $0.019^{*}$ & $0.019^{*}$ \\
Heterosis (H.) & $(12)$ & $0.551^{*}$ & 0.039 & $0.010^{*}$ & $0.004^{*}$ \\
Average H. & 1 & 0.027 & 0.018 & $0.066^{*}$ & 0.000 \\
H. Line (A) & 2 & $0.545^{*}$ & 0.018 & 0.0004 & 0.002 \\
H. Line (R) & 3 & $0.568^{*}$ & 0.029 & $0.012^{*}$ & $0.003^{*}$ \\
Specific H. & 6 & $0.632^{*}$ & 0.054 & $0.003^{*}$ & $0.006^{*}$ \\
Error & 72 & 0.092 & 0.027 & 0.001 & 0.001 \\
\hline Overall mean & & -0.253 & -0.057 & 0.052 & -0.008 \\
\hline Lines A & & -0.323 & -0.015 & -0.046 & -0.030 \\
Lines R & & -0.209 & -0.079 & 0.109 & 0.013 \\
Experimental hybrids & & -0.250 & -0.060 & 0.057 & -0.009 \\
\hline
\end{tabular}

*Significant by the F-test, at 5\% probability. Lines A, male-sterile lines; lines $\mathrm{R}$, fertility-restorer lines. the varietal heterosis. For GMP, a varietal heterotic effect was found for lines A and R, mainly lines A1 and R2. For TSS and MBH, the effect of varietal heterosis was observed only for the lines R, especially lines R1 and R2, respectively (Table 4). These lines were distinguished by their positive varietal heterotic effects, which results in higher hybrid combinations. Meanwhile, for the performance per se, the increase of phenotypic expression, line R1 stood out.

For the accumulation rate of GMP, TSS, and MBH traits, there was also a significant specific heterotic effect (Table 5). The $\mathrm{H}_{22}$ hybrid showed significant specific heterosis of positive magnitude for all traits, followed by the hybrids $\mathrm{H}_{14}$ and $\mathrm{H}_{31}$, which showed a positive heterotic effect for GMP and MBH (Table 4). Nevertheless, when evaluating the performance per se of these hybrids, it was observed that they did not always show an increase of the phenotypic expression, especially the hybrids $\mathrm{H}_{14}$ and $\mathrm{H}_{22}$ (Table 2).

As to predictability, heterosis occurred for all traits (Table 6). The traits showed significance regarding the average heterosis. For GMP, there was a significant varietal heterosis only for the lines $\mathrm{R}$; and the line

Table 6. Summary of the partial diallel analysis of the predictability $\left(\mathrm{r}^{2}\right)$ over the harvest times, for the traits green mass production (GMP, $\mathrm{Mg} \mathrm{ha}^{-1}$ ), juice extraction (EXT, $\%$ ), total soluble solids (TSS, \% juice), and megagrams of Brix per hectare $(\mathrm{MBH})$ of sweet sorghum genotypes, in the municipalities of Lavras and Sete Lagoas, of Minas Gerais state, Brazil, in the 2014/2015 growing season.

\begin{tabular}{|c|c|c|c|c|c|}
\hline \multirow{2}{*}{$\begin{array}{l}\text { Source of } \\
\text { variation }\end{array}$} & \multirow{2}{*}{$\begin{array}{l}\text { Degree of } \\
\text { freedom }\end{array}$} & \multicolumn{4}{|c|}{ Mean square } \\
\hline & & GMP & EXT & TSS & $\mathrm{MBH}$ \\
\hline Genotype & (18) & $0.393^{*}$ & $0.687^{*}$ & $0.392 *$ & $0.529 *$ \\
\hline Between lines & 1 & 0.034 & $1.325^{*}$ & $1.863^{*}$ & 0.031 \\
\hline Line A & 2 & 0.01 & $2.043^{*}$ & 0.167 & 0.134 \\
\hline Line $\mathrm{R}$ & 3 & $0.212 *$ & $0.181^{*}$ & $0.616^{*}$ & $0.221 *$ \\
\hline Heterosis (H.) & (12) & $0.531 *$ & $0.535^{*}$ & $0.251^{*}$ & $0.714^{*}$ \\
\hline Average $\mathrm{H}$. & 1 & $0.859^{*}$ & $1.095^{*}$ & $0.742^{*}$ & $3.287 *$ \\
\hline H. Line (A) & 2 & 0.205 & $0.852 *$ & $0.277^{*}$ & $0.398^{*}$ \\
\hline H. Line (R) & 3 & $0.498^{*}$ & $0.583^{*}$ & $0.226^{*}$ & $0.852 *$ \\
\hline Specific $\mathrm{H}$. & 6 & $0.602 *$ & $0.312 *$ & $0.172 *$ & $0.321 *$ \\
\hline Error & 72 & 0.083 & 0.078 & 0.058 & 0.067 \\
\hline Overall mean & & 0.420 & 0.408 & 0.649 & 0.444 \\
\hline Lines A & & 0.501 & 0.240 & 0.476 & 0.587 \\
\hline Lines $\mathrm{R}$ & & 0.455 & 0.437 & 0.703 & 0.528 \\
\hline Experimental hybrids & & 0.387 & 0.440 & 0.674 & 0.381 \\
\hline
\end{tabular}

*Significant by the F-test, at $5 \%$ probability. Lines A, male-sterile lines; lines $\mathrm{R}$, fertility-restorer lines. 
R1 was the most prominent because of its positive heterotic effect (Table 4). In turn, for EXT, TSS, and $\mathrm{MBH}$, there were varietal heterotic effects for the lines $\mathrm{A}$ and R, especially the A3 and R1 for EXT, and A1 and R1 for TSS and MBH.

There was specific heterosis for all traits, mainly in the lines $\mathrm{H}_{13}$ and $\mathrm{H}_{24}$ for GMP; $\mathrm{H}_{21}, \mathrm{H}_{33}$, and $\mathrm{H}_{34}$ for EXT; $\mathrm{H}_{12}, \mathrm{H}_{24}$, and $\mathrm{H}_{31}$ for TSS; and $\mathrm{H}_{11}, \mathrm{H}_{13}$, and $\mathrm{H}_{34}$ for $\mathrm{MBH}$ (Tables 4 and 6). However, the performance per se of these lines and hybrids was not always predictable, that is, the adopted model (linear) did not always explain the existing variation, indicating the lower reliability in its recommendation (Table 2), mainly for the lines A1 and R1, and for the hybrids $\mathrm{H}_{11}$, $\mathrm{H}_{12}, \mathrm{H}_{21}$, and $\mathrm{H}_{31}$.

Considering the heterosis obtained for the mean performance, the accumulation rate and the predictability of the behavior over the harvest times, the lines (A and $\mathrm{R}$ ) and the hybrids were not always coincident with the positive heterotic effect, mainly when traits were evaluated separately. Therefore, the emphasis on the lines and hybrids with higher mean performance was chosen, followed by the higher accumulation rate and the predictability of the behavior over the harvest times. The most promising genotypes were those showing the higher performance per se, followed by higher heterosis, namely, the lines A1, R1, and R3, and the hybrids $\mathrm{H}_{11}, \mathrm{H}_{13}, \mathrm{H}_{14}, \mathrm{H}_{21}, \mathrm{H}_{22}$, and $\mathrm{H}_{33}$.

\section{Conclusions}

1. Heterosis is relevant for hybrid breeding in sweet sorghum (Sorghum bicolor).

2. The lines A1, R1, and R3 show a better potential per se, considering all traits and their accumulation rate and predictability in the different harvest times.

3. The hybrids $\mathrm{H}_{11}, \mathrm{H}_{13}, \mathrm{H}_{14}, \mathrm{H}_{21}, \mathrm{H}_{22}$, and $\mathrm{H}_{33}$ are promising genotypes because of their better performance per se and higher heterosis.

\section{Acknowledgments}

To Coordenação de Aperfeiçoamento de Pessoal de Nível Superior (Capes) and to Embrapa Milho e Sorgo, for funding this research.

\section{References}

BORÈM, A.; PIMENTEL, L.; PARRELLA, R.A.C. (Ed.). Sorgo do plantio à colheita. Viçosa: Ed. da UFV, 2014. p.138-275.

BUNPHAN, D.; JAISIL, P.; SANITCHON, J.; KNOLL, J.E.; ANDERSON, W.F. Heterosis and combining ability of F1 hybrid sweet sorghum in Thailand. Crop Science, v.55, p.178-187, 2015. DOI: 10.2135/cropsci2014.05.0363.

CRUZ, C.D. GENES: a software package for analysis in experimental statistics and quantitative genetics. Acta Scientiarum. Agronomy, v.35, p.271-276, 2013. DOI: 10.4025/ actasciagron.v35i3.21251.

CRUZ, C.D.; REGAZZI, A.J.; CARNEIRO, P.C.S. Modelos biométricos aplicados ao melhoramento genético. 4.ed. Viçosa: Ed. da UFV, 2012. p.223-375.

CRUZ, C.D.; VENCOVSKY, R. Comparação de alguns métodos de análise dialélica. Revista Brasileira de Genética, v.12, p.425438, 1989.

ELANGOVAN, M.; KIRAN BABU, P.; SEETHARAMA, N.; PATIL, J.V. Genetic diversity and heritability characters associated in sweet sorghum [Sorghum bicolor (L.) Moench]. Sugar Tech, v.16, p.200-210, 2014. DOI: 10.1007/s12355-013-0262-5.

EPE. Empresa de Pesquisa Energética. Balanço Energético Nacional 2015: ano base 2014. Rio de Janeiro, 2015. cap.2: Oferta e demanda de energia por fonte. p.41-75. Available at: $<$ http://www.epe.gov.br/ sites-pt/publicacoes-dados-abertos/publicacoes/PublicacoesArquivos/ publicacao-127/topico-97/Relat\%C3\%B3rio\%20Final\%202015.pdf>. Accessed on: Mar. 302017.

GARDNER, C.O.; EBERHART, S.A. Analysis and interpretation of the variety cross diallel and related populations. Biometrics, v.22, p.439-452, 1966. DOI: 10.2307/2528181.

KIM, M.; DAY, D.F. Composition of sugar cane, energy cane, and sweet sorghum suitable for ethanol production at Louisiana sugar mills. Journal of Industrial Microbiology and Biotechnology, v.38, p.803-807, 2010. DOI: 10.1007/s10295-010-0812-8.

KULKARNI, N.; SHINDE, V.K. Heterosis and inbreeding depression in grain sorghum. Indian Journal of Agricultural Sciences, v.55, p.505-509, 1985.

LOMBARDI, G.M.R.; NUNES, J.A.R.; PARRELLA, R.A.C.; TEIXEIRA, D.H.L.; BRUZI, A.T.; DURÃES, N.N.L.; FAGUNDES, T.G. Path analysis of agro-industrial traits in sweet sorghum. Genetics and Molecular Research, v.14, p.1639216402, 2015. DOI: 10.4238/2015.December.9.8.

MIRANDA FILHO, J.-B. de; GERALDI, I.O. An adapted model for the analysis of partial diallel crosses. Revista Brasileira de Genética, v.7, p.677-688, 1984.

PEREIRA, J.A.; MORAIS, O.P. de; BRESEGHELLO, F. Análise da heterose de cruzamentos entre variedades de arroz-vermelho. Pesquisa Agropecuária Brasileira, v.43, p.1135-1142, 2008.

PFEIFFER, T.W.; BITZER, M.J.;TOY, J.J.; PEDERSEN, J.F. Heterosis in sweet sorghum and selection of a new sweet sorghum hybrid for use in syrup production in Appalachia. Crop Science, v.50, p.1788-1794, 2010. DOI: 10.2135/cropsci2009.09.0475. 
POTHISOONG, T.; JAISIL, P. Yield potential, heterosis and ethanol production in $F_{1}$ hybrids of sweet sorghum (Sorghum bicolor L. Moench.). Kmitl Science and Technology Journal, v.11, p.17-21, 2011.

R CORE TEAM. R: a language and environment for statistical computing. Vienna: R Foundation for Statistical Computing, 2016.

REDDY, B.V.S.; RAMESHS, S.; REDDY, P.S.; RAMAIAH, B. Combining ability and heterosis as influenced by male-sterility inducing cytoplasms in sorghum [Sorghum bicolor (L.) Moench]. Euphytica, v.154, p.153-164, 2007. DOI: 10.1007/s10681-0069281-6.

REGASSA, T.H.; WORTMANN, C.S. Sweet sorghum as a bioenergy crop: literature review. Biomass and Bioenergy, v.64, p.348-355, 2014. DOI: 10.1016/j.biombioe.2014.03.052.

RESENDE, M.D.V. de; DUARTE, J.B. Precisão e controle de qualidade em experimentos de avaliação de cultivares. Pesquisa Agropecuária Tropical, v.37, p.182-194, 2007.
SANTOS, F.S. dos; PLÁCIDO, H.F.; GARCIA, E.B.; CANTÚ, C.; ALBRECHT, L.P.; FRIGO, K.D. de A. Sorgo sacarino na produção de agroenergia. Revista Brasileira de Energias Renováveis, v.4, p.1-12, 2015. DOI: 10.5380/rber.v3i3.39690.

SANTOS, H.G. dos; JACOMINE, P.K.T.; ANJOS, L.H.C. dos; OLIVEIRA, V.A. de; OLIVEIRA, J.B. de; COELHO, M.R.; LUMBRERAS, J.F.; CUNHA, T.J.F. (Ed.). Sistema brasileiro de classificação de solos. 2.ed. Brasília: Embrapa, 2006. 306p.

SCAPIM, C.A.; RODRIGUES, J.A.S.; CRUZ, C.D.; CECON, P.R.; RIBEIRO JÚNIOR, J.I.; BRACCINI, A. de L. Efeitos gênicos, heterose e depressão endogâmica em caracteres de sorgo forrageiro. Bragantia, v.57, 1998. DOI: 10.1590/S000687051998000100010 .

SOUZA, R.S. e; PARRELLA, R.A. da C.; SOUZA, V.F. de; PARRELLA, N.N.L.D. Maturation curves of sweet sorghum genotypes. Ciência e Agrotecnologia, v.40, p.46-56, 2016. DOI: 10.1590/S1413-70542016000100004.

Received on March 30, 2017 and accepted on August 14, 2017 